\title{
Allergenic Ambrosia pollen grains in the air of some Polish cities in 2019
}

\author{
Aneta Sulborska', Elżbieta Weryszko-Chmielewska', Piotr Rapiejko ${ }^{2,3}$, Katarzyna Dąbrowska-Zapart ${ }^{4}$, \\ Dariusz Jurkiewicz ${ }^{2}$, Ewa Kalinowska ${ }^{3}$, Małgorzata Puc ${ }^{5}$, Agnieszka Lipiec ${ }^{6}$, Małgorzata Malkiewicz', \\ Zenon Siergiejk0 ${ }^{8}$ \\ ${ }^{1}$ Department of Botany and Plant Physiology, University of Life Sciences in Lublin, Poland \\ ${ }^{2}$ Department of Otolaryngology with Division of Cranio-Maxillo-Facial Surgery in Military Institute of Medicine, \\ Warsaw, Poland \\ ${ }^{3}$ Allergen Research Center, Warsaw, Poland \\ ${ }^{4}$ Faculty of Natural Sciences, Institute of Earth Sciences, University of Silesia in Katowice, Poland \\ ${ }^{5}$ Institute of Marine \& Environmental Sciences, University of Szczecin, Poland \\ ${ }^{6}$ Department of Prevention of Environmental Hazards and Allergology, Medical University of Warsaw, Poland \\ ${ }^{7}$ Laboratory of Paleobotany, Department of Stratigraphical Geology, Institute of Geological Sciences, \\ University of Wroclaw, Poland \\ ${ }^{8}$ Laboratory of Respiratory Diagnostics and Bronchoscopy, Medical University of Bialystok, Poland
}

\begin{abstract}
:
Ambrosia is regarded as the most dangerous allergy-related plant posing a considerable threat to human health with its highly allergenic pollen. In Europe, there are 4 Ambrosia species originating from North America; they most often colonize ruderal habitats and agricultural fields. The aim of the study was to compare Ambrosia pollen seasons in 9 cities located in different parts of Poland in 2019. Aerobiological tests were conducted in Bialystok, Bydgoszcz, Lublin, Olsztyn, Piotrkow Trybunalski, Sosnowiec, Szczecin, Warsaw, and Wroclaw. The investigations were carried out with the volumetric method using Burkard or Lanzoni pollen samplers. The $98 \%$ method was used to determine the duration of the pollen season. The earliest onset of the pollen season was recorded in Szczecin (August $7^{\text {th}}$ ) and Sosnowiec (August $9^{\text {th }}$ ), whereas the latest beginning was noted in Wroclaw (August 22 $2^{\text {nd }}$ ) and Bydgoszcz (August 215). The longest pollen season was recorded in Sosnowiec (52 days) as well as Lublin and Szczecin (50 days), while the shortest pollen season was noted in Wroclaw (10 days). The highest mean daily concentrations of Ambrosia pollen grains were recorded in Sosnowiec $\left(104 \mathrm{P} / \mathrm{m}^{3}\right)$ and Wroclaw $\left(77 \mathrm{P} / \mathrm{m}^{3}\right)$, whereas the lowest value was obtained in Szczecin $\left(18 \mathrm{P} / \mathrm{m}^{3}\right)$. Peak days were noted mostly during the last 10 days of August. The highest value of Ambrosia annual pollen sum was reported from Sosnowiec (326) and Lublin (310), while the lowest sum was noted in Szczecin (69). The multimodal course of the graph presenting the pollen seasons in the analysed cities and literature data indicate that the pollen originated not only from local sources but also from long-distance transport. The highest risk of Ambrosia pollen-induced allergy in sensitive subjects was demonstrated in Lublin, Piotrkow Trybunalski and Warsaw. The concentration of Ambrosia pollen in the air of the analysed Polish cities was substantially lower than the values indicated by measurement stations located in other parts of Europe.
\end{abstract}

Key words: aeroallergens, pollen concentration, risk of allergy, Ambrosia 2019

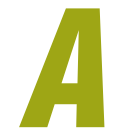
mbrosia pollen grains are extremely allergenic; hence, ragweed jest regarded as the most dangerous allergy-related plant [1]. Ambrosia pollen is one of the most allergenic pollen types in Europe [2]. 4 species naturalised in Europe but origi- nating from North America, i.e. Ambrosia artemisiifolia, A. coronopifolia, A. trifida and A. elatior, are the sources of Ambrosia pollen [3,4]. These plants most frequently grow in ruderal and riparian habitats and often colonise agricultural fields [5]. As shown by 
data collected by the European Allergenic Network, the mean pollen index for ragweed calculated based on data from 368 measurement stations is 697, with a maximum value of 14590 . The ragweed most often occurs in Central and Eastern Europe [4].

In Poland, for many years, the highest concentrations of ragweed pollen have been recorded in Lublin, with the maximum pollen index from 13 years reaching 1200 and the mean value of this index of 388 [6]. In turn, the maximum values of the Ambrosia pollen index recorded in multiyear studies (10-13 years) in other cities were lower, i.e. 399, 425, 460 , and 474 in Wroclaw, Lodz, Cracow, and Sosnowiec, respectively [7-10].

In Poland, Ambrosia pollen constitutes a small proportion of the airborne pollen spectrum. It was found that, on average, the pollen of this taxon accounted for $3 \%$ in Lodz [8] and $0.65 \%$ in Lublin [11]. A greater share of ragweed pollen in the aeroplankton was demonstrated in Ukraine (Vinitsa), where 8-year investigations showed that Ambrosia pollen constituted $2-23 \%$ of the pollen spectrum with a mean of $6.6 \%$ [12].

A measure of the strong allergenic effect of Ambrosia pollen on the organism of sensitive individuals is the occurrence of the first symptoms of allergy already in the presence of 1-3 pollen grains in $1 \mathrm{~m}^{3}$ of air within 24 hours $[13,14]$. Other authors have reported that allergic reaction may occur at a concentration of $12-13$ pollen grains $/ \mathrm{m}^{3}$ of air/day $[15,16]$, or 20 pollen grains $/ \mathrm{m}^{3}$ of air/day [17].

Previous studies have shown development of allergy to Ambrosia pollen allergens in $11 \%$ of patients in Poland [18]. As reported by Rodinkova [12], Ambrosia pollen grains are more allergenic for children than for the adult population in Ukraine.

Ambrosia pollen grains are classified as small $(\sim 20 \mu \mathrm{m})$; hence, they can be transported by air over long distances [19]. Many studies indicate a long-distance transport of Ambrosia pollen in Europe, e.g. from France to Switzerland [20], from France, Italy, and Croatia to Hungary [21], from Pannonian Plain to Poland [22-25], from Ukraine to Poland [26], and from Central and South Europe to the United Kingdom and the Netherlands [27].

Aim

The aim of this research was to compare $\mathrm{Am}$ brosia pollen concentrations recorded in 2019 in the air of nine cities in Poland: Bialystok, Bydgoszcz, Lublin, Olsztyn, Piotrkow Trybunalski, Sosnowiec, Szczecin, Warsaw, and Wroclaw.

\section{Material and method}

Airborne Ambrosia pollen was recorded with the standard volumetric method using Burkard or Lanzoni pollen traps manufactured based on the Hirst-type sampler [28]. The pollen traps were placed on the roofs of the buildings in the analysed cities and operated on a continuous basis. Daily mean pollen concentrations were expressed as the number of pollen grains per cubic meter of air $\left(\mathrm{P} / \mathrm{m}^{3}\right)$. The duration of the pollen season was determined with the $98 \%$ method. The pollen season patterns were represented in graphs. The analyses included the onset and length of the pollen season, the maximum concentration, the date of peak days, and the annual pollen sum.

The threshold values of $5 \mathrm{P} / \mathrm{m}^{3}$ and $20 \mathrm{P} / \mathrm{m}^{3}$ served for determination of the degree of allergy risk during the Ambrosia pollen season according to literature data $[17,29]$.

\section{Results}

In 2019, the earliest onset of the Ambrosia pollen season was recorded in Szczecin (August $7^{\text {th }}$ ) followed by Sosnowiec (August $9^{\text {th }}$ ) as well as Lublin and Piotrkow Trybunalski (August 12 $2^{\text {th }}$ ). The latest beginning of the pollen season of this taxon was noted in Wroclaw (August 22 $2^{\text {nd }}$ ) and Bydgoszcz (August 21 ${ }^{\text {st }}$ ) (tab. 1).

An extremely short Ambrosia pollen season was recorded in Wroclaw (10 days). In turn, the pollen season persisted for 30-39 days in Piotrkow Trybunalski, Bydgoszcz, Olsztyn, and Bialystok and 45-52 days in Warsaw, Lublin, Szczecin, and Sosnowiec. As demonstrated by a majority of the measurement stations, the end of the pollen season of this taxon was noted in the last 10 days of September.

The maximum daily concentration of Ambrosia pollen grains was recorded between August $27^{\text {th }}$ and September $1^{\text {st }}$ in seven of the measurement stations (tab. 1). The peak day was noted on September $9^{\text {th }}$ only in Bialystok and Olsztyn.

The graphic representations of the pollen seasons in all cities in 2019 showed the presence of several peaks (figs 1-5). Such multimodal graphs may indicate that the pollen originates from long-distance transport.

The highest peak values were recorded in Sosnowiec, Wroclaw, Bialystok, and Lublin, i.e. 104, 77, 59, and 59 pollen grains in $1 \mathrm{~m}^{3}$, whereas the lowest value of this parameter was noted in Szczecin $\left(18 \mathrm{P} / \mathrm{m}^{3}\right)$.

In 2019, the highest annual sum of Ambrosia pollen was recorded in Sosnowiec (326) and Lublin 


\section{ORIGINAL PAPER}

Table 1. Characteristics of ragweed pollen season in 2019.

\begin{tabular}{|c|c|c|c|c|c|c|c|c|c|}
\hline $\begin{array}{l}\text { Features of pollen } \\
\text { season }\end{array}$ & Bialystok & Bydgoszez & Lublin & Olsztyn & $\begin{array}{l}\text { Piotrkow } \\
\text { Trybunalski }\end{array}$ & Sosnowiec & Szczecin & Warsaw & Wroclaw \\
\hline $\begin{array}{l}\text { Duration of pollen } \\
\text { season } \\
\text { (number of days) }\end{array}$ & $\begin{array}{c}19.08- \\
26.09 \\
(39)\end{array}$ & $\begin{array}{c}21.08- \\
25.09 \\
(36)\end{array}$ & $\begin{array}{c}12.08- \\
30.09 \\
(50)\end{array}$ & $\begin{array}{c}19.08- \\
24.09 \\
(37)\end{array}$ & $\begin{array}{c}12.08- \\
10.09 \\
(30)\end{array}$ & $\begin{array}{c}9.08- \\
29.09 \\
(52)\end{array}$ & $\begin{array}{c}7.08- \\
25.09 \\
(50)\end{array}$ & $\begin{array}{c}18.08- \\
1.10 \\
(45)\end{array}$ & $\begin{array}{c}22.08- \\
31.08 \\
(10)\end{array}$ \\
\hline Annual pollen sum & 128 & 174 & 310 & 104 & 273 & 326 & 69 & 224 & 150 \\
\hline \multirow{2}{*}{$\begin{array}{l}\text { Peak value and peak } \\
\text { date }\end{array}$} & 59 & 29 & 59 & 24 & 43 & 104 & 18 & 37 & 77 \\
\hline & 9.09 & 30.08 & 29.08 & 9.09 & 31.08 & 28.08 & 1.09 & 29.08 & 27.08 \\
\hline Days $\geq 5 \mathrm{P} / \mathrm{m}^{3}$ & 6 & 9 & 14 & 5 & 12 & 8 & 4 & 12 & 4 \\
\hline Days $\geq 20 \mathrm{P} / \mathrm{m}^{3}$ & 2 & 3 & 6 & 1 & 4 & 5 & 0 & 4 & 2 \\
\hline
\end{tabular}

Figure 1. Ragweed pollen count in Bialystok and Olsztyn in 2019.

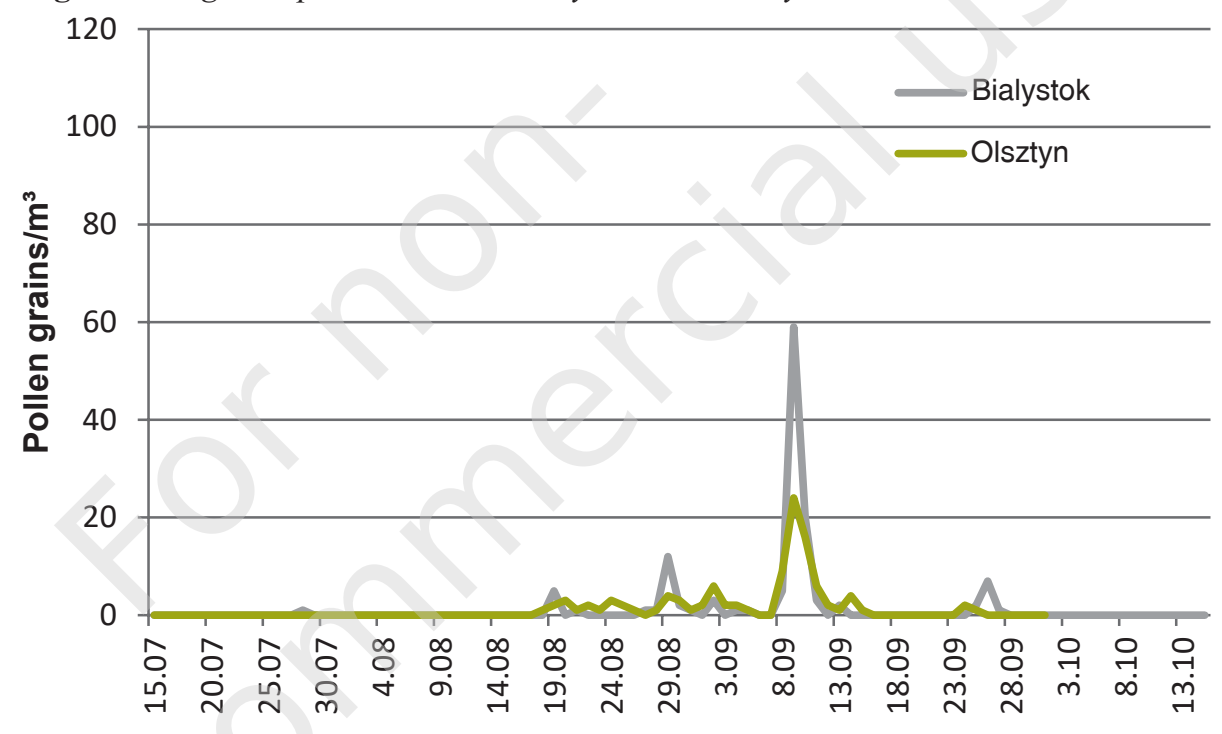

Figure 2. Ragweed pollen count in Bydgoszcz and Szczecin in 2019.

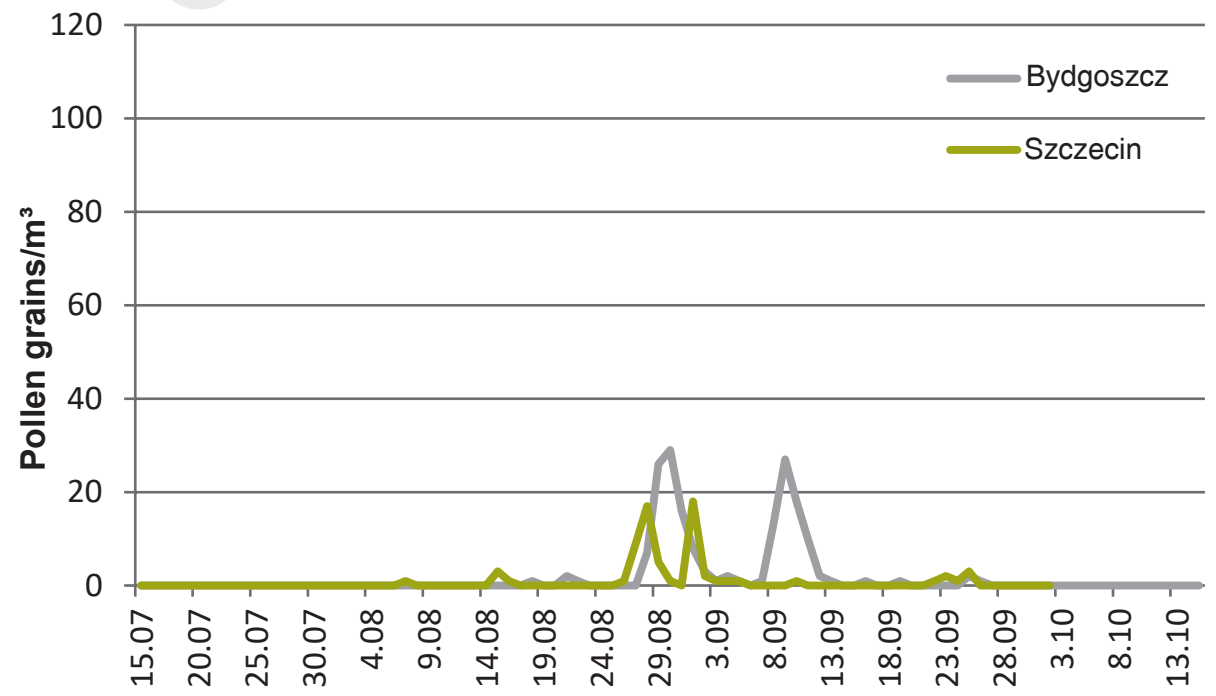


Figure 3. Ragweed pollen count in Sosnowiec and Wroclaw in 2019.

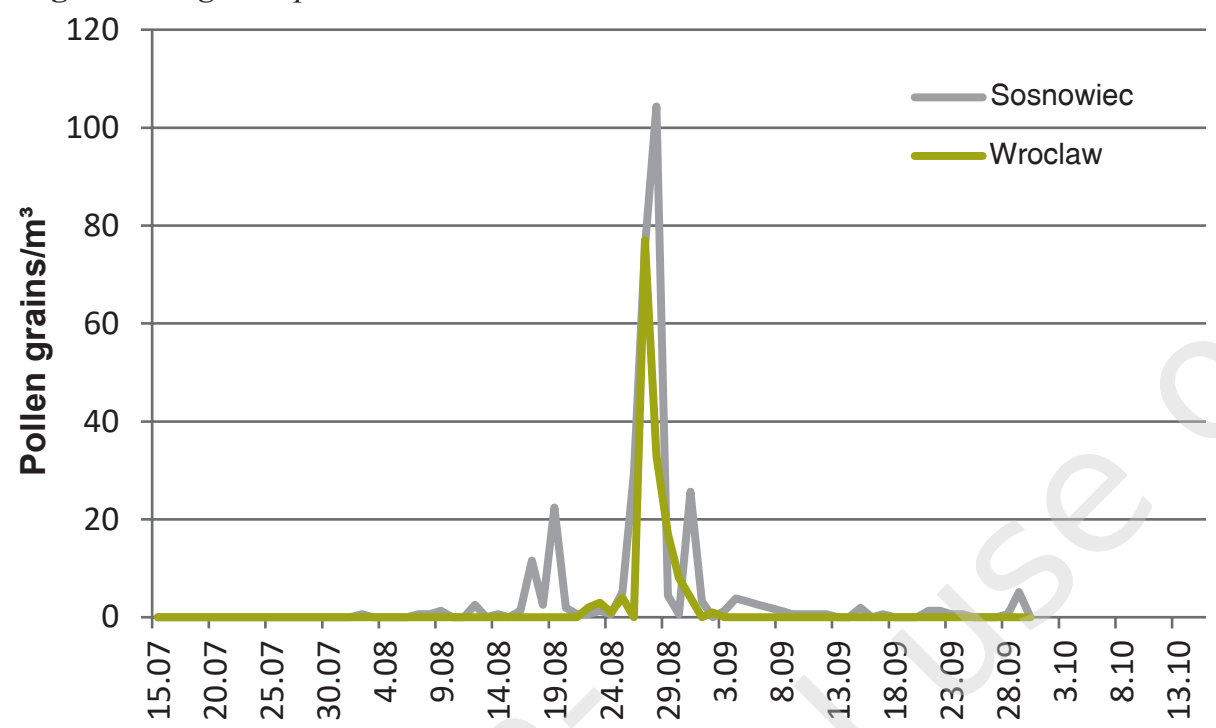

Figure 4. Ragweed pollen count in Piotrkow Trybunalski and Warsaw in 2019.

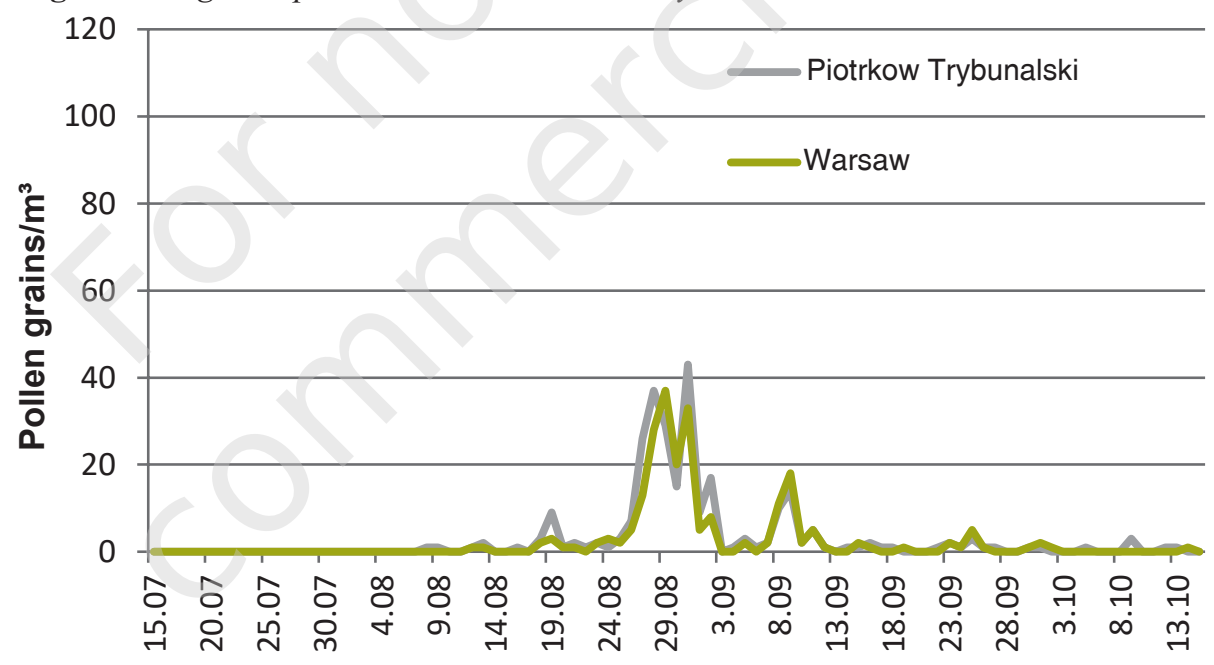

Figure 5. Ragweed pollen count in Lublin in 2019.

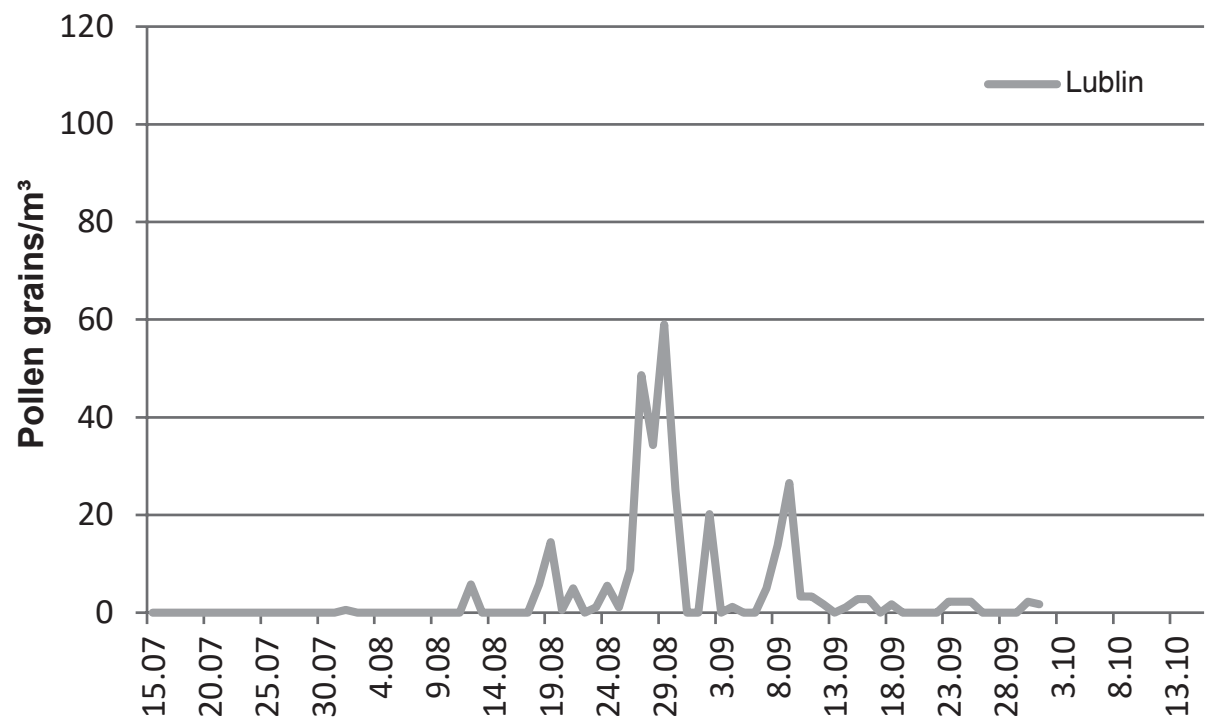


(310) and the lowest value was noted in Szczecin (69). The mean value of this parameter for the 9 analysed cities in this year was 195 .

The greatest risk of allergy related to the largest number of days with the exceeded threshold value of $5 \mathrm{P} / \mathrm{m}^{3}$ was noted in Lublin (14 days), Piotrkow Trybunalski (12 days), and Warsaw (12 days). In turn, the highest frequency of concentrations exceeding $20 \mathrm{P} / \mathrm{m}^{3}$ was recorded in Lublin (6 days), Sosnowiec (5 days), Piotrkow Trybunalski (4 days), and Warsaw (4 days) (tab. 1).

\section{Discussion}

In 2019, the Ambrosia pollen seasons in the analysed cities started between August $7^{\text {th }}$ and August $22^{\text {nd }}$. This was similar to the dates recorded in 2016 for many cities in Poland $[30,31]$ and differed from the results from 2018, in which the first Ambrosia pollen grains were recorded already on July $26^{\text {th }}$ [32].

The results of the annual Ambrosia pollen sum obtained in 2019 indicate a large spatial variation in the concentration of the pollen of this taxon in Poland (69326). This parameter differed significantly between the measurement stations in 2018 [32] and in 2016 $[30,31]$.

Multiyear research conducted in Lublin showed substantially higher concentrations of Ambrosia pollen than the values recorded in other Polish cities $[6,7,10]$. The annual sum of Ambrosia pollen (83) reported in Lublin in 2016 was the lowest of the values recorded in 6 cities, with a several-fold higher value noted in Zielona Gora (371). Similarly, higher abundance of Ambrosia pollen was recorded in Opole and Zielona Gora than in Lublin in 2018 [32]. The investigations conducted in 2019 showed the highest annual pollen sums in Sosnowiec (326) followed by Lublin (310).

The concentrations of Ambrosia pollen were not high in 2019. The mean annual sum of Ambrosia pollen recorded in the 9 measurement stations in the study year was substantially lower (195) than the mean calculated for many cities in $2016(295)$ [30, 31] and the mean noted in 2018 (291) [32].

As demonstrated in the present study, the Ambrosia pollen concentrations recorded in Poland are considerably lower than in many other European countries. This is reflected in the high mean pollen index (697) calculated for 368 measurement stations in Europe [4], which substantially exceeds the values reported by aerobiological stations in Poland.

Ambrosia pollen recorded in Poland is not only released by plants growing in the country, but also originates primarily from distant transport. As demonstrated by Stępalska et al. [33], the high Ambrosia pollen concentrations in the southeastern part of Poland are associated with the pollen transport with air mass inflow from the east-south and south-west and with local sources.

The presence of airborne Ambrosia pollen in the first half of August, which was noted in 2019 in Sosnowiec, Szczecin, Lublin and Piotrkow Trybunalski, intensified the human health risk due to the co-occurrence of the Artemisia pollen season. This is also highlighted by authors of previous papers on the pollen of both these taxa [33].

\section{Conclusions}

1. In 2019, the Ambrosia pollen season in most of the Polish cities analysed in the study began in the first or second 10 day period in August, i.e. ca. 10 days later than in 2018.

2. The pollen season of the investigated taxon was substantially shorter in 2019 than in 2018.

3. The maximum ragweed pollen concentration in 2019 was most frequently recorded at the end of August or in the first 10 days of September.

4. The highest risk of Ambrosia pollen-induced allergy in patients was noted in Lublin, Piotrkow Trybunalski and Warsaw.

\section{References}

1. Makra L, Matyasovszky I, Hufnagel L et al. The history of ragweed in the world. Appl Ecol Env Res 2015, 13(2): 489-512 .

2. Sofiev M, Bergmann KC (eds). Allergenic pollen: a review of the production, release, distribution and health impacts. Springer, Dordrecht 2013. DOI: 10.1007/978-94-007-4881-1.

3. Rapiejko P. Alergeny pytku roślin. Medical Education, Warszawa 2010.

4. Skjøth CA, Šikoparija B, Jäger S; EAN-Network. Pollen sources. In: Sofiev M, Bergmann K-Ch (eds). Allergenic Pollen. Springer, Dordrecht, Heidelberg, New York, London 2013: 9-27.

5. Hansen A. Ambrosia L. In: Tutin TG, Heywood NA, Burges DM et al (eds). Flora Europaea. Cambridge University Press, Cambridge, London, New York, Melbourne 1976.

6. Weryszko-Chmielewska E, Piotrowska-Weryszko K. Charakterystyka sezonów pytkowych wybranych taksonów roślin w Lublinie w latach 2001-2013. In: Weryszko-Chmielewska E (ed). Ziarna pytku i zarodniki grzybów w powietrzu różnych regionów Polski. Norbertinum, Lublin 2014. 
7. Malkiewicz M. Dynamika sezonów pytkowych drzew (Alnus, Corylus, Betula) i roślin zielnych (Ambrosia, Artemisia, Poaceae) w powietrzu Wroctawia w latach 2003-2013. In: Weryszko-Chmielewska E (ed). Ziarna pyłku i zarodniki grzybów w powietrzu różnych regionów Polski. Norbertinum, Lublin 2014.

8. Majkowska-Wojciechowska B, Balwierz Z, Kowalski ML. Sezonowa dynamika stężeń pyłku najczęściej uczulających drzew, traw i chwastów w Łodzi, w latach 2003-2013. In: Weryszko-Chmielewska E (ed). Ziarna pyłku i zarodniki grzybów w powietrzu różnych regionów Polski. Norbertinum, Lublin 2014.

9. Myszkowska D, Ziemianin M, Piotrowicz K et al. Analiza sezonów pytkowych wybranych taksonów roślin $w$ Krakowie w latach 2011-2013. In: Weryszko-Chmielewska E (ed). Ziarna pyłku i zarodniki grzybów w powietrzu różnych regionów Polski. Norbertinum, Lublin 2014.

10. Dąbrowska-Zapart K, Chtopek K. Dynamika sezonów pytkowych wybranych taksonów roślin $w$ powietrzu Sosnowca w latach 2001-2013. In: Weryszko-Chmielewska E (ed). Ziarna pyłku i zarodniki grzybów w powietrzu różnych regionów Polski. Norbertinum, Lublin 2014.

11. Piotrowska-Weryszko K, Weryszko-Chmielewska E. The airborne pollen calendar for Lublin, central-eastern Poland. AAEM 2014, 21(3): 541-545.

12. Rodinkova VV. Airborne pollen spectrum and hay fever type prevalence in Vinnitsa, central Ukraine. Acta Agrobotanica 2015, 68(4): 383-389.

13. Comtois P, Gagnon L. Pollen concentration and frequency of pollinosis symptoms: Method of determination of the clinical threshold. Revue Française d'Allergologie 1988, 28: 279 -286 .

14. Thibaudon M. Allergy risk associated with pollens in France. Eur Ann Allergy Clin Immunol 2003, 35: 170-172.

15. Banken R, Comtois P. Concentration de l'herbe à poux et prévalence de la rhinite allergique dans deux municipalités des Laurentides. L'Unión Médeicale du Canada 1990, 119: 178-182.

16. Zink $K$, Vogel H, Vogel B et al. Modeling the dispersion of Ambrosia artemisiifolia L. pollen with the model system COSMO-ART. Int J Biometeorol 2012, 56(4): 669-680.

17. Jäger S. Global aspects of ragweed in Europe. In: Spieksma FThM (ed). Ragweed in Europe. $6^{\text {th }}$ International Congress of Aerobiology. Perugia, Italy 1998. Satellite Symposium Proceedings, Alk-Abelló A/S, Horsholm DK: 6-10.

18. Heinzerling LM, Burbach GJ, Edenharter $G$ et al. GA2 LEN skin test study I: GA'LEN harmonization of skin prick testing: novel sensitization patterns for inhalant allergens in Europe. Allergy 2009, 64(10): 1498-1506.

19. Weryszko-Chmielewska E. Aerobiologia. Wydawnictwo Akademii Rolniczej, Lublin 2007.
20. Clot B, Schneiter D, Tercier Ph et al. Ambrosia pollen in Switzerland: Local production or transport? Allergie at Immunologie 2002, 34: 126-128.

21. Makra L, Palfi S. Intra-regional and long-range ragweed pollen transport over southern Hungary. Acta Climatologica et Chorologica 2007, 40-41: 69-77.

22. Stach A, Smith M, Skjøth CA et al. Examining Ambrosia pollen episodes at Poznan (Poland) using back-trajectory analysis. Int J Biometeorol 2007, 51: 275-286.

23. Smith M, Skjøth CA, Myszkowska D et al. Long-range transport of Ambrosia pollen to Poland. Agric For Meteorol 2008, 148(10): 1402-1411.

24. Sikoparija B, Skjøth CA, Alm Kübler K et al. A mechanism for long distance transport of Ambrosia pollen from the Pannonian Plain. Agric For Meteorol 2013, 180: 112-117.

25. Grewling Ł, Bogawski P, Jenerowicz P et al. Mesoscale atmospheric transport of ragweed pollen allergens from infected to uninfected areas. Int J Biometeorol 2016. DOI: 10.1007/ s00484-016-1139-6.

26. Kasprzyk I, Myszkowska D, Grewling Ł et al. The occurrence of Ambrosia pollen in Rzeszów, Kraków and Poznań, Poland: investigation of trends and possible transport of Ambrosia pollen from Ukraine. Int J Biometeorol 2011, 55(4): 633-644.

27. de Weger LA, Pashley CH, Sikoparija B et al. The long distance transport of airborne Ambrosia pollen to the UK and the Netherlands from Central and south Europe. Int J Biometeorol 2016. DOI: 10.1007/s00484-016-1170-7.

28. Hirst JM. An automatic volumetric spore trap. Ann Appl Biol 1952, 39(2): 257-265.

29. Taramarcaz P, Lambelet C, Clot B et al. Ragweed (Ambrosia) progression and it's health risks: will Switzerland resist this invasion? Swiss Med Wkly 2005, 135: 538-548.

30. Piotrowska-Weryszko K, Weryszko-Chmielewska E, Lipiec A et al. Ragweed pollen season in southern Poland in 2016. Alergoprofil 2016, 12(4): 182-185.

31. Puc M, Kotrych D, Rapiejko P et al. Ragweed pollen season in the cities of northern Poland in 2016. Alergoprofil 2016, 12(4): 178-181.

32. Weryszko-Chmielewska, Woźniak A, Piotrowska-Weryszko K et al. Ambrosia pollen season in selected cities in poland in 2018. Alergoprofil 2018, 14(4): 111-116.

33. Stępalska D, Myszkowska D, Leśkiewicz $K$ et al. Co-occurence of Artemisia and Ambrosia pollen seasons against the backgroung of the synoptic situations in Poland. J Biometeorol 2016. DOI: 10.1007/s00484-016-1254-4.

ORCID

A. Sulborska - ID - orcid.org/0000-0002-7720-0719

E. Weryszko-Chmielewska - ID - orcid.org/0000-0001-8410-2757

P. Rapiejko - ID - orcid.org/0000-0003-3868-0294

K. Dabrowska-Zapart - ID - orcid.org/ 0000-0002-8976-7739

D. Jurkiewicz - ID - orcid.org/0000-0003-3729-2679

E. Kalinowska - ID - orcid.org/ 0000-0003-4821-6882 
M. Puc - ID - orcid.org/0000-0001-6734-9352

A. Lipiec - ID - orcid.org/0000-0003-3037-2326

M. Malkiewicz - ID - orcid: 0000-0001-6768-796

Z. Siergiejko - ID - orcid: 0000-0002-3876-5135

Author's contributions: Sulborska A.: aerobiological data Lublin, writing a manuscript, literature review;

Weryszko-Chmielewska E.: aerobiological data Lublin, work concept, writing a manuscript, proofreading.

Rapiejko P.: aerobiological data Bydgoszcz, work concept;

Dąbrowska-Zapart K.: aerobiological data Sosnowiec;

Jurkiewicz D.: aerobiological data Piotrkow Trybunalski;

Kalinowska E.: aerobiological data Olsztyn;

Puc M.: aerobiological data Szczecin;

Lipiec A.: aerobiological data Warsaw;
Malkiewicz M.: aerobiological data Wroclaw;

Siergiejko Z:: aerobiological data Bialystok.

Conflict of interests: The authors declare that they have no competing interests.

Ethics: The contents presented in this paper are compatible with the rules the Declaration

of Helsinki, EU directives and standardized requirements for medical journals.

Financial support: not applicable.

\section{Corresponding author:}

Aneta Sulborska, PhD

Department of Botany and Plant Physiology University of Life Sciences in Lublin

20-950 Lublin, Akademicka 15

e-mail: aneta.sulborska@up.lublin.pl 